Next of Kin 
A book in the series

LATIN AMERICA OTHERWISE:

LANGUAGES, EMPIRES, NATIONS

A series edited by

Walter D. Mignolo, Duke University

Irene Silverblatt, Duke University

Sonia Saldívar-Hull, University of Texas,

San Antonio 


\section{Next of Kin}

The Family in Chicano/a Cultural Politics

Richard T. Rodríguez 
C 2009 Duke University Press

All rights reserved

Printed in the United States of America on acid-free paper $\infty$

Designed by Heather Hensley

Typeset in Warnock Pro by Achorn International

Library of Congress Cataloging-inPublication Data appear on the last printed page of this book. 